\title{
Preparing teachers to integrate Web 2.0 in school practice: Toward a framework for Pedagogy 2.0
}

\author{
Athanassios Jimoyiannis, Panagiotis Tsiotakis, Dimitrios Roussinos, and Anastasia Siorenta \\ Department of Social and Educational Policy, University of Peloponnese, Greece
}

\begin{abstract}
Web 2.0 has captured the interest and the imagination of both educators and researchers while it is expected to exert a significant impact on instruction and learning, in the context of the 21 st century education. Hailed as an open collaborative learning space, many questions remain unanswered regarding the appropriate teacher preparation and the pedagogical impact of using Web 2.0 tools in the classroom practice. Do teachers feel comfortable and ready to adopt educational Web 2.0? What are their beliefs and perceptions regarding the educational potential of Web 2.0? What are the educational and contextual issues that determine teachers' challenges and decisions to use Web 2.0 in their classroom practice? This paper addresses the questions above by presenting the design and the implementation of a development program aiming to prepare teachers to make meaningful and purposeful use of Web 2.0 tools in their classroom. The model of technological pedagogical content knowledge and the authentic learning approach were the guiding principles that largely influenced the Web 2.0 pedagogical framework, which was designed and applied in this particular teacher preparation program. The program findings were encouraging as far as the participants' perceptions and beliefs towards educational Web 2.0 and the expected outcomes for the students. Implications and recommendations are drawn in relation to the use of the proposed Web 2.0 pedagogical framework to guide teachers' development and the effective implementation of Web 2.0 tools in the classroom to maximize benefits and enhance students' learning.
\end{abstract}

\section{Introduction}

During the past decade, the nature of the Web and the way people access and use web resources for personal, educational, employment, entertainment and other social purposes, have been fundamentally changed. The browser is becoming the universal interface to a range of new generation Web tools and media storing applications. In addition, the Web has been transformed from a space where users passively retrieve information, delivered by a small group of experts (Web 1.0), to a participatory, read/write platform (Web 2.0) which broadens users' communication capabilities and enables content distribution, sharing, co-creation, and remixing through participatory practices. Web 2.0 is a collective term for a series of Web-based technologies that include blogging and microblogging platforms, wikis, mediasharing sites, podcasting, content aggregators, social networks, social bookmarking sites, and other emerging forms of participatory and social media. Timothy O'Reilly (2005), generally accepted to be the originator of the notion of Web 2.0 (Anderson, 2007), has focused on the architecture of participation in contrast to the passive consumption of information. Therefore, we can broadly define the second generation of Web applications as more personalised and communicative Web spaces that support active participation, connectivity, collaboration and sharing of knowledge and ideas among users.

While students are increasingly using new generation technologies, such as social networks, text messaging, media sharing, blogs, wikis, and other Web 2.0 applications, to communicate and collaborate, this is not the case for many educators (Pence, 2007; Underwood, 2007). Current views and perceptions of learning determine the way that educational Web 2.0 has driven pedagogy so that teachers need to know, not only how to use the Web 2.0 tools for personal purposes but how to use them to support and enhance their students' learning. The use of Web 2.0 is expected to exert a significant impact on instruction and learning since it provides multiple opportunities for students' engagement, communication, active and self-directed learning, while it offers shared content and resources and promotes collaborative learning (Dede, 2008; McLoughlin \& Lee, 2010; Glassman \& Kang, 2010). In addition, Web 2.0 technologies extend students' learning spaces (both physical and virtual) beyond the walls of the classroom, while they can bridge learning and instruction spaces across school, home, and the wider community (Jimoyiannis, 2010b). 
Over the last few years, Web 2.0 applications, and especially blogs, wikis, e-portfolios, social media, podcasting, social networking etc., have received intense and growing educational interest, with uses including diverse learning groups, from primary and secondary education (Tse, Yuen, Loh, Lam, \& Ng, 2010, Sheehy, 2008; Woo, Chu, Ho, \& Li, 2011; Angelaina \& Jimoyiannis, 2011) to higher education (Bolliger \& Shepherd, 2010; Ching \& Hsu, 2011; Deng \& Yuen, 2011; Roussinos \& Jimoyiannis, 2011; Yang, 2009; Zorko, 2009), vocational training (Marsden \& Piggot-Irvine, 2012) and teachers' professional development (Doherty, 2011; Wheeler, \& Wheeler, 2009; Wopereis, Sloep, \& Poortman , 2010).

The present article reports upon the design, the implementation and the outcomes of a Web 2.0 program aiming to prepare primary and secondary teachers to develop meaningful representations and make purposeful use of Web 2.0 tools in their classroom. The teacher professional development program and the related study were implemented in the context of an EU supported project, entitled Web2.0 European Resource Centre (http://www.web20erc.eu), aiming at the development of a simplified technological and pedagogical framework to use Web 2.0 tools for educational purposes. The Web 2.0 pedagogical framework presented here considers Web 2.0 not as a simple technology but as a learning attitude to be cultivated by both teachers and students. The integrated pedagogical framework proposed was rooted on the Technological Pedagogical Content Knowledge (TPACK) model (Mishra \& Koehler, 2006) and the authentic learning approach (Herrington \& Kervin, 2007).

An empirical post-course investigation was established using an online anonymous questionnaire. The findings indicated that the proposed framework helped teachers to acquire the knowledge and skills to integrate Web 2.0 in their instruction. In addition, they showed enhanced teachers' awareness of the benefits of Web 2.0 to extend in-class learning activities and improve students' learning, and readiness to adopt and apply Web 2.0 technologies in their classroom. The great majority of the teachers reported that this program had a positive impact into their development. They considered that pedagogical and school factors are critical and determine teachers' intentions and efforts to put Web 2.0 into practice. The paper concludes that providing authentic professional development and active learning opportunities could help teachers to adopt Web 2.0 as an important and efficient tool to be integrated in educational practice.

The article is structured as follows: the first section addresses both theoretical foundations and instructional design aspects regarding Web 2.0 pedagogy; after this, the educational design of the teacher training program and the consequent research methodology are presented. Finally, empirical research findings are analytically presented and discussed. Conclusions are drawn for educational practice and further research in the area.

\section{Theoretical foundations of Web 2.0 pedagogical framework}

\section{Teachers and information and communication technologies (ICTs)}

Teacher education programs are globally revisited and revised. Historically, research, educational policy and accreditation requirements have been the impetus for renewal in teacher education. For the past 20 years, ICTs have played an increasingly significant role in rethinking teachers' education and professional development. Preparing teachers to use ICT effectively in the classroom is a key issue in the context of the 21 st century education objectives, in both policy and learning design perspectives. Teachers must be proficient in using ICT not only to support their professional productivity and development (e.g., course attendance, presenting content, developing supportive material) but, mainly, to effectively integrate ICT into instruction and learning.

Existing literature, regarding the integration of ICT in schools, shows that despite governmental efforts and directives, the application of ICT in educational settings is rather peripheral acting, in most cases, as an 'add on' effect to regular teacher-centred classroom work. It remains a common practice, for most teachers, to use ICT primarily for low-level formal academic tasks (e.g., getting information from Web resources) or for administrative purposes (developing lesson plans, worksheets, assessment tests, etc.) rather than as a learning tool to support students' active learning (OFSTED, 2004; Jimoyiannis \& Komis, 2007; Tondeur, van Keer, van Braak, \& Valcke , 2008). 
Previous research showed that effective teacher preparation is an important factor for successful integration and sustainability of ICT in education (Hennessy et al., 2007; Davis, Preston, \& Sahin, 2009). On the other hand, most ICT teacher professional development initiatives tend to focus on technological aspects (i.e., how to use various tools) while pedagogical and instructional issues (i.e., why and how to use those tools to enhance learning) are often taken for granted (Jimoyiannis, 2008). As a consequence, the application of ICT in school settings has been driven more by the accordance of technology rather than by the demands of pedagogy and didactics of the particular subject matter. In this context, it is imperative to conceive the educational use of Web 2.0 not in terms of a 'special event' or an 'extra tool' supplemental to the traditional instruction but in terms of well-defined pedagogical dimensions.

\section{Defining educational Web 2.0}

During the last decade the debate about the gap between the students' enthusiasm to use information and communication technologies and their slow uptake by the instructors, higher institutions and the schools was dominant (Holden, Ozok, \& Rada , 2008; Jimoyiannis \& Komis, 2007; OFSTED, 2011; Prensky, 2001; Pence, 2007; Tondeur et al., 2008; Wikan \& Molster, 2011). As such, there is a growing reason to believe that ICTs are fundamentally altering many young people's relationships with information. However, other researchers showed that the net generation students are far from being homogeneous regarding their ICT skills and suggested a new debate context beyond the gap of natives and immigrants (Kennedy, Judd, Dalgarno, \& Waycott , 2010; Bennett, Maton, \& Kervin , 2008). A recent Pew report (Zickuhr, 2010) found that while the youngest generations are still significantly more likely to use social media, older generations are making notable gains. In addition a large scale survey in the USA conducted by ECAR (Dahlstrom, de Boor, Grunwald, \& Vockley, 2011) showed that higher education students already own and use an array of technologies, and especially social media. On the other hand, institutions and instructors do not fully harness them to create opportunities for more varied, inspiring, and beyondthe-classroom learning experiences (Dahlstrom et al., 2011, p. 6).

Social media and Web 2.0 applications were not designed specifically for educational purposes. In addition, existing literature shows that the application of conventional tools (e.g., office applications, multimedia, educational software, concept mapping and Web tools) in educational settings is rather peripheral, acting in most cases, as an isolated 'add on' effect to regular teacher-centered classroom work rather than as a learning tool to support students' active learning (Holden et al., 2008; Jimoyiannis \& Komis, 2007; Levin \& Wadmany, 2008; Wikan \& Molster, 2011). It is reasonable, therefore, that teachers are less receptive to the learning opportunities offered by Web 2.0 tools than their students. Web 2.0 directed learning activities can be troublesome for the teachers, since they often demand extra time and efforts for their design and preparation, at both a technical and pedagogical level. Additionally, teachers face at particular difficulties to manage Web 2.0 based learning tasks and plan students' support. Therefore, the need for describing an integrated educational framework for Web 2.0 seems very considerable.

However, during the last decade, Web 2.0 received intense and growing educational and research interest. The key idea was that Web 2.0 tools have a number of affordances that transform the learning context by providing multiple opportunities for shared content and resources, self-directed learning, collaborative learning, ubiquitous and lifelong learning (Clark et al., 2009; Ravenscroft, 2009; McLoughlin \& Lee, 2010; Glassman \& Kang, 2010). Because of its read/write nature, Web 2.0 offers new learning environments based upon the user-centred, participative and social networking characteristics embedded. It is therefore expected that the emerging socially directed technologies of Web 2.0 have the potential to offer enhanced learning opportunities by supporting students' participation, informal conversation and reflexive dialogue, and by enabling access to a wide range of ideas and representations, collaborative content generation, lifelong competence and the development of online learning identity.

In conclusion, there are three key arguments for drawing Web 2.0 into education:

a) The first is that the forms of learning activities cultivated within Web 2.0 are widely endorsed as important by current thinking of the nature of learning that 21 st century education must provide and the theoretical perspectives of pedagogy as well (Vygotsky, 1978; Pea, 2004; Stahl, 2005). Actually, there is a match with current overarching policy and curriculum goals. This approach is based on contemporary pedagogy associated with the need to shift from traditional instruction formats towards student-centred and collaborative approaches. 
b) Web 2.0 tools offer enhanced learning opportunities by strengthening students' critical thinking, writing, and reflection; and engaging students in a new world of information sharing and social learning. Research findings in recent years provide compelling evidence of the importance of encouraging students' control over the learning process as a whole. Within appropriate educational contexts, Web 2.0 tools can be transformed into effective task-oriented personal learning spaces by shifting control to the learners, extending formal learning into a more informal one, promoting learner autonomy and participation in social networks independently of physical, geographical and institutional boundaries (Siemens 2005; Hall \& Hall, 2010; Ravenscroft, 2009).

c) The third and most straightforward is the aforementioned students' readiness to adopt Web 2.0 as an effective learning environment. Indeed, the majority of young people are already engaged by Web 2.0 in their personal and social lives out of school (e.g., social networking). So, students are already prepared and familiar with new forms of interaction and inquiry that arise from browsing within Web 2.0 spaces. Educational settings constitute an ideal context and a meaningful environment to promote creative ways of using Web 2.0 applications offering, in parallel, a lifelong benefit to the students.

Towards achieving the main objective of this program, e.g., helping the teachers to cultivate an overall pedagogical view of Web 2.0, we tried to determine the starting point for the design of the project's training courses. This was the assumption that formal instruction remains based on the 'classical' view of knowledge and learning, where the didactic paradigm is prevalent. On the other hand, there is an imperative need for the teachers to acknowledge that Web 2.0 changes the key aspects of the nature of knowledge and the way students access it. This means that teachers need to understand how Web 2.0 transforms the traditional learning context by providing multiple opportunities for shared content and resources, self-directed learning, collaborative learning, and ubiquitous and lifelong learning. In conclusion, the educational Web 2.0 operates as a platform which redefines 'what students learn', 'how students learn' and 'where and with whom students learn'.

The coursework of the teachers' development program was directed to help participants to built meaningful representations and cultivate Web 2.0 not as a simple technology but as a learning platform and a learning attitude to be integrated in school practice. In order to integrate the technological, social and learning features of Web 2.0 in a meaningful way for the participating teachers, we defined the educational Web 2.0 by revealing six interrelated aspects-dimensions: (Figure 1).

Participatory web: This aspect is rooted in the features of Web 2.0 tools which promote students' engagement and make publication an easy task for both teachers and students. In addition, Web 2.0 changes the ways of learners' inquiry and reflection by offering effective personal learning environments for the students (e.g., blogs, wikis, e-portfolios etc.)

Open web: The open features inherent in Web 2.0 support creativity through learner generated content and peer review, and the evolution of a collective intelligence within the Web 2.0 environments.

Collaboration: Web 2.0 tools can effectively support collaborative work and learning through discovering, sharing and transforming media, co-creating new content, concepts, ideas and, finally, developing new forms of thinking.

Sociability: Web 2.0 offers enhanced opportunities for communication and interaction among participants, developing social groups and networks (social networking), and at the end supporting autonomous communities of learning.

Open classroom: Web 2.0 transforms the notion of classroom by extending students' learning spaces (both physical and virtual) beyond the walls of the classroom. This new conception changes the boundaries between school and home, formal, non formal and informal learning, educators and learners, education and entertainment. In addition, Web 2.0 offers an open window-channel for communication between the classroom and the parents, the local community, experts in specific disciplinary fields, other schools at national and international level etc., thus supporting blended learning and ubiquitous learning. 
Web as a learning platform: This conception is tightly related to the five notions above which determine the new learning paradigm supported by Web 2.0. This paradigm is based on participation, creativity, collaboration, sociability, open learning and the development of sustainable learning systems and learning ecologies). In this context, Web 2.0 is not considered as a simple technology but as a learning platform and a learning attitude, for both students and teachers.

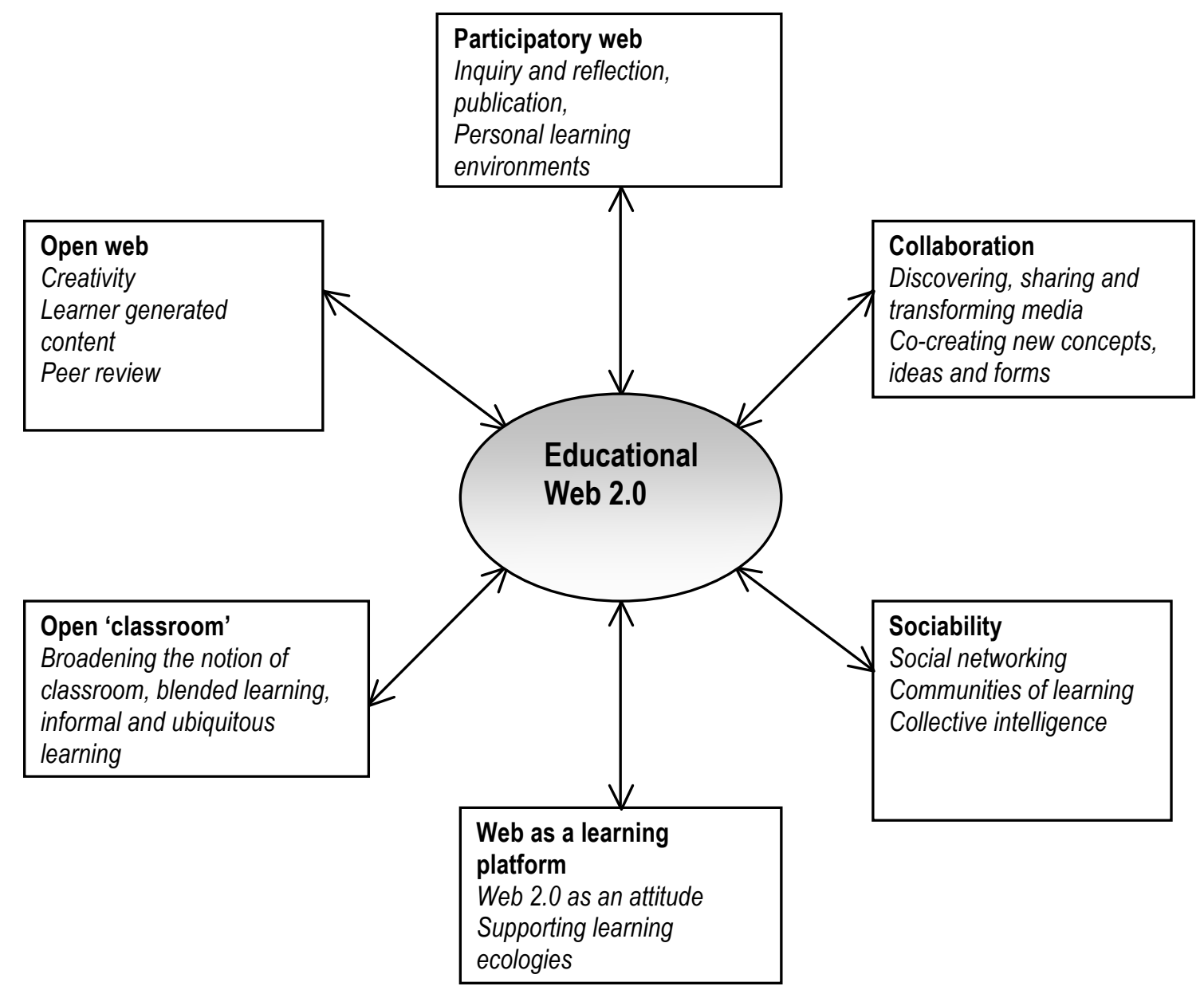

Figure 1. Conceptualising the educational Web 2.0.

In summary, the following key-principles underpin the proposed pedagogical framework for integrating Web 2.0 in educational practice which was applied in the pilot courses implemented at the Department of Social and Educational Policy, University of Peloponnese, in Greece:

1. Moving from teaching to learning: Supporting learners' engagement and autonomy (learn how to learn), active and reflective learning, and collaborative learning

2. Moving beyond constructivism: Supporting authentic learning, students are content creators, using networking to built collective intelligence among students.

3. Moving beyond the classroom boundaries: Using blended learning principles, opening the classroom to the wider community, cultivating ubiquitous and lifelong learning.

4. Teachers need to develop new roles: The teachers in Web 2.0 environments act as learning designers while they provide to their students learning support and facilitation, scaffolding and mentoring.

\section{TPACK 2.0: Web 2.0 technological pedagogical content knowledge}

Technological pedagogical content knowledge (TPACK) was firstly proposed by Mishra and Koehler (2006) to describe an integrated framework to clarify the critical parameters relating to technology integration in classroom settings. Since its formal introduction as a theoretical concept, TPACK has been 
transformed into a promising framework to aid ICT integration in school practice. There is extended research evidence that TPACK allows teachers and teacher educators to focus upon the connections among technology, content, and pedagogy as they correlate in real instructional-classroom contexts (Koehler \& Mishra, 2009; So \& Kim, 2009; Doering, Veletsianos, Scharber, \& Miller, 2009; Lee \& Tsai, 2009; Jimoyiannis, 2010a)

Consequently, viewing teachers' knowledge in terms of the interplay among Web 2.0, Pedagogy, and Content, may have significant implications for their professional development needs in order to achieve Web 2.0 integration into instructional practice. Figure 2 presents an adaptation for TPACK in relation to Web 2.0 technologies, called TPACK 2.0 hereafter, which guided the curriculum and the coursework in the teacher preparation pilot courses presented in this paper. To our knowledge, this study is the first attempt contributing to the direction of a consistent TPACK framework for the educational Web 2.0.

The TPACK 2.0 model goes beyond seeing the three constitutional knowledge elements, namely: Web 2.0 technologies, Content and Pedagogy, in isolation but in the complex relationship system they define. It emphasizes the connections and the complex relationships between them and defines three new dimensions-areas of knowledge: a) Pedagogical Content Knowledge, b) Technological Content Knowledge, and c) Technological Pedagogical Knowledge.

Web 2.0 content knowledge

Pedagogical content knowledge

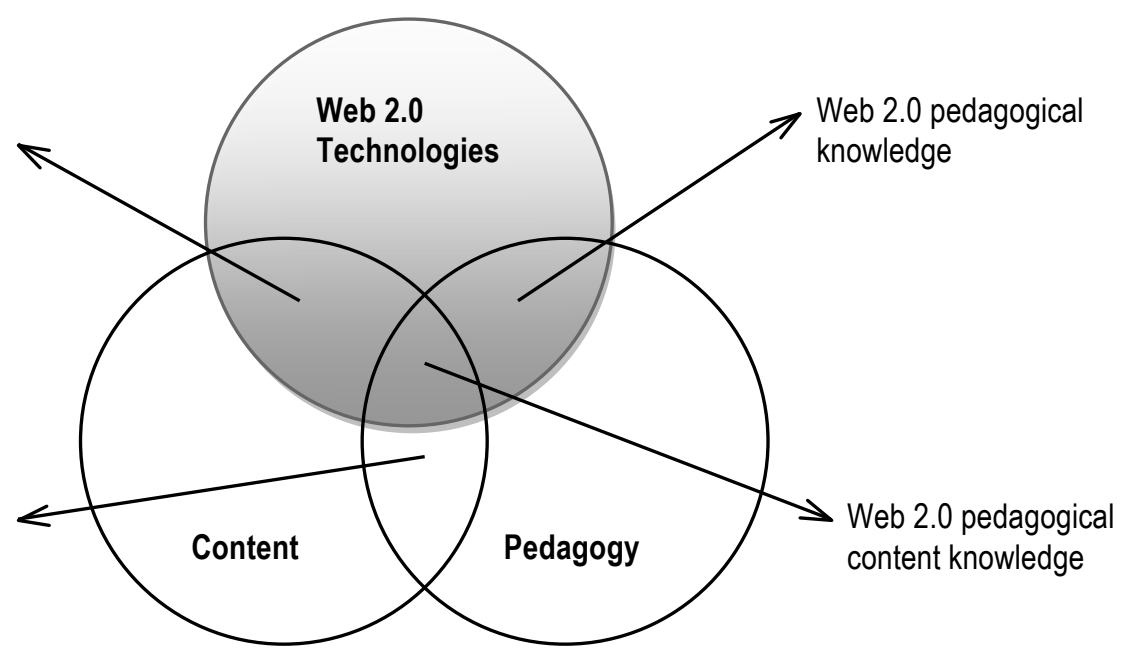

Figure 2. TPACK for Web 2.0 technologies (TPACK 2.0 model).

Pedagogical content knowledge: It is a notion introduced by Shulman (1986), representing the knowledge of pedagogy that is applicable to the instruction of specific content (for example, schemata and representations used to describe content knowledge, students' pre-existing knowledge and learning difficulties, effective pedagogical strategies in practice etc.).

Technological content knowledge: This dimension describes teachers' knowledge of how specific units of subject matter under study are transformed by the application of specific Web 2.0 tools (for example, new methods and changes that Web 2.0 brings regarding content representation, new ways of content creation and sharing among students and teachers through the various tools, e.g., educational blogs, educational wikis, collaborative concept mapping etc.).

Technological pedagogical knowledge: This includes the knowledge of the pedagogical affordances of Web 2.0 technologies and the knowledge of how Web 2.0 can support specific pedagogical strategies or goals in the classroom (e.g., fostering inquiry learning, supporting collaborative or reflective learning, facilitating project activities etc.).

In summary, the TPACK 2.0 model offers new approaches for treating a complex task, like enhancing teachers' knowledge and skills necessary to support meaningful and productive integration of Web 2.0 technologies in the classroom. 


\section{Design and implementation of the coursework}

\section{The project courses}

This European Union funded project, under the title "Simplifying Web 2.0 for educational purposes", was designed to help educators, who find Web 2.0 confusing, to have a simple and secure environment to use Web 2.0 in their classes with their students. In this context, pilot courses were established in the countries of the project partners. In Greece, the Department of Social and Educational Policy at the University of Peloponnese has deployed and implemented different courses, addressed to both university students and teachers. In this paper, the teacher developmental program, under the title 'Web 2.0 tools in Practice', is presented. The aim of the program was the preparation of the participating teachers, coming from the area near the city of Korinthos, for purposeful applying Web 2.0 tools in their instruction. The course sessions and the related instructional activities were implemented between February and April 2011.

\section{The participants}

In total, 86 primary and secondary teachers participated in the pilot courses (26 male and 60 female). They were divided into four independent groups, two for each level (primary and secondary). 42 teachers (20 primary and 22 secondary) were enrolled in the first run of the course (February - March 2011) and 44 teachers (22 primary and 22 secondary) were enrolled in the second run (March - April 2011). The participants were selected on a voluntary basis while they cover several criteria, e.g., ranging age, teaching experience, ICT competence, academic degrees, etc. They were between 25-60 years old and they had a teaching experience ranging between 3 and 30 years, $82 \%$ of the participants had a bachelor degree, $17 \%$ had MSc degree and one teacher had a PhD. They were familiar with computers and the Web, while $76 \%$ attended training programs on basic ICT and general purpose software skills. In addition, $61 \%$ of the participants reported that they attended training programs related to pedagogical and instructional themes.

\section{Implementing TPACK 2.0}

A potential danger of grounding teachers' professional development in traditional classroom practice is reproducing the very approaches that a professional development program aims to change. Existing literature indicated that it may be important to design professional development so that teachers experience learning in new and different settings (Putnam \& Borko, 2000). Our previous research and experience regarding teachers' ICT professional development shows that teachers are willing to develop new knowledge and skills, related to their own instructional needs, in meaningful and realistic learning settings, i.e., learning activities that are easily implemented and integrated in their classroom. Therefore, when planning this professional development project, we tried to keep a balance between introducing new ways of conceptualizing the teaching and learning processes with the realities of classroom instruction, both seen interrelated through the lens of TPACK 2.0. This study ambitiously extends the TPACK model by embodying Web 2.0 learning activities in participants' coursework, which were planned in an integrated framework determined by TPACK 2.0 and the authentic learning approach (Herrington \& Kervin, 2007).

Establishing an authentic learning context and putting the focus on the teachers, the course sessions were addressed to encourage participants to think about how to use Web 2.0 tools, in both the technological and the pedagogical perspectives, in their own instructional context. Therefore, teachers were engaged in solving instruction problems and critical situations through designing authentic Web 2.0 learning scenarios. Learning through design embodies a process of constructing Web 2.0 artefacts applicable in school practice (e.g., designing complete learning activities and scenarios based on blogs, wikis, Webquests etc.) using multiple sources and perspectives, and promoting teachers' participation, collaboration and reflection.

\section{Workflow of the courses}

The workflow of the courses followed a blended learning philosophy. Each course was scheduled for four face-to-face (FtF) workshops delivered at the computer laboratory ( 20 hours in total). There was little direct instruction about particular software or tools during these courses. More common were 
spontaneous and short tutorial sessions driven by the immediate requirements of the participants to cover the needs of the coursework. Individual and collaborative coursework were properly interwoven to achieve the objectives. The instructor (the first author) and his assistants (the next two) were also the facilitators in teachers' lab work and online activities. Teachers were encouraged to acquire the knowledge and skills mainly through engagement and experience, reflection on issues presented during lecture time, discussion with colleagues, imitation, and studying the material related to the educational Web 2.0 which was produced by our group.

The online aspect of the courses, i.e., communication with peers and the instructors, individual and collaborative work (downloading learning materials, learning tasks assigned, seeking information through suggested resources from the Web, peer communication and ideas exchange, content sharing etc.), was delivered through the Web 2.0 featured platform set by the project (Wojtowicz, Walczak, Wiza, \& Ruminski , 2011). In addition, participants were exposed to detailed discussions, both face-to-face and online through the Web 2.0 platform, about the affordances and the pedagogical uses of Web 2.0 tools (educational blog, wiki, WebQuests etc.).

Figure 3 outlines the blended structure of teachers' project work, which combines FtF sessions, and online activities from both the computer lab at the university and from personal spaces. The teachers were engaged into the project platform not only during the face-to-face sessions but also in time and place outside the university. The development of the course workflow (timeline) was structured into five phases, corresponding to five working weeks, as shown in Table 1.

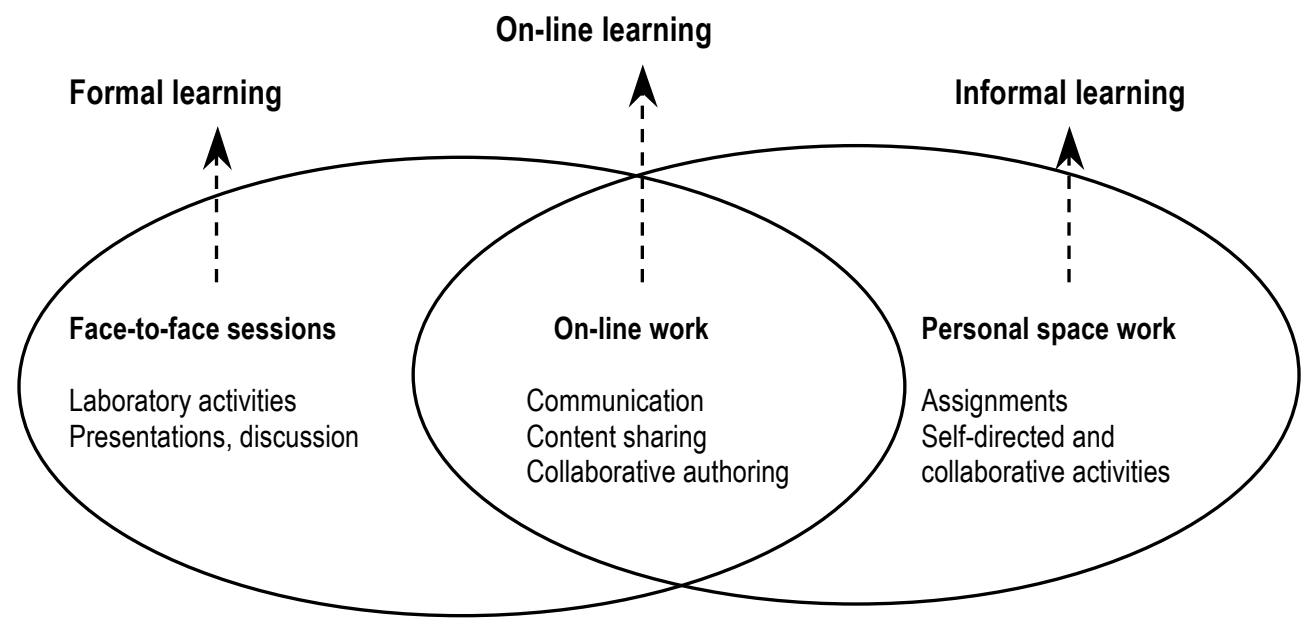

Figure 3. The blended structure of the project courses.

\section{Research context}

\section{Research objectives}

There are four main purposes justifying this study. We hypothesized that, in particular, the present study could offer information useful:

- to record participants' views and experiences of the program and, especially, whether the desired outcomes of the educational uses of Web 2.0 have been achieved

- to evaluate the impact of the program on teachers' perceptions and views of the educational Web 2.0 as a learning space and its integration in education

- to identify teachers' decisions or intentions to put into practice what they had learned during the courses

- to identify difficulties or other related factors that influence their efforts to integrate Web 2.0 in educational practice. 
Table 1

Workflow of the Web 2.0 project courses

\begin{tabular}{|c|c|}
\hline Project phase & Activities \\
\hline \multirow[t]{10}{*}{ Week 1} & Face-to-face session (4 hours) \\
\hline & Introduction to the Web 2.0 project (objectives, time frames, and modes of work) \\
\hline & Introduction to Web 2.0 \\
\hline & Basic tools (blogs, wikis, e-portfolios, social bookmarking etc.) \\
\hline & Familiarisation with the Web 2.0 platform - Teachers' registration \\
\hline & FtF discussion on the affordances of Web 2.0 \\
\hline & Web 2.0 pedagogical issues \\
\hline & Online session: Individual and group work through the Web 2.0 platform \\
\hline & Use of sources and learning material on the Web 2.0 platform \\
\hline & Assignment 1: Discussion forum on the platform (Web 2.0 and pedagogy) \\
\hline \multirow[t]{7}{*}{ Week 2} & Face-to-face session (4 hours) \\
\hline & Presentation of Web 2.0 tools and platforms \\
\hline & Blogs and wikis \\
\hline & Learning design principles and pedagogical issues \\
\hline & Online session: Individual and group work through the Web 2.0 platform \\
\hline & Assignment 2: Blogging activity on the Web 2.0 platform \\
\hline & Teachers' engagement in blogging \\
\hline \multirow[t]{10}{*}{ Week 3} & Face-to-face session (4 hours) \\
\hline & Presentation of Web 2.0 tools \\
\hline & Media sharing, social bookmarking \\
\hline & Webquests and e-portfolios \\
\hline & Learning activities design (Webquests) \\
\hline & Organisational and pedagogical issues \\
\hline & Online session: Individual and group work through the Web 2.0 platform \\
\hline & Assignment 3: Wiki activity on the Web 2.0 platform \\
\hline & Collaborative wiki authoring \\
\hline & Discussion and exchanging ideas \\
\hline
\end{tabular}

Week 4 Online session: Individual and group work through the Web 2.0 platform

Assignment 4: Design of a Web 2.0 learning activity (blog, wiki, WebQuest etc.)

Teachers' engaged into learning design

Discussion forum on the Web 2.0 platform

Week 5 Face-to-face session (4 hours): Closing meeting

Teachers presented the Web 2.0 learning activities they designed

Discussion and exchanging ideas on pedagogical and instructional issues

Summary and integration

Program closing, conclusions 


\section{The instrument}

The instrument was an online anonymous questionnaire developed by the researchers. The design was based upon the theoretical knowledge already known from the literature (Jimoyiannis, 2008) and the practical knowledge and the research experience of the researchers. The questionnaire contained a 26 items scale presenting statements of perceptions and beliefs towards Web 2.0 and the educational use of Web 2.0 in classroom practice. A 5-point Likert-type scale ranged from 1 (strongly disagree) to 5 (strongly agree) was used. There were four dimensions represented in the scale, aiming at teachers' perceptions and beliefs of:

- Web 2.0 in relation to current instruction

- $\quad$ use of Web 2.0 in classroom practice

- $\quad$ the educational potential of Web 2.0

- the integration of Web 2.0 in education.

In addition, there were five items related to teachers' experience with Web 2.0 and five items representing teachers' use of ICT in educational practice, before entering the program. Finally, six open-ended questions were also included, through which we expected to authentically record teachers' perceptions of (a) the educational potential of Web 2.0 tools and (b) the impact of the Web 2.0 professional development program they attended. Demographic information such as gender, age, university degrees, teaching subject-specialty, years of teaching experience, type and level of school, ICT training, and professional development and pedagogical training, was also requested.

\section{The procedure}

The survey on teachers' perceptions of Web 2.0 in education was administered six weeks after the courses had been completed. This delay was intentional and was designed to allow teachers (a) to apply their knowledge and skills regarding the educational Web 2.0 in classroom practice, and (b) to adequately assess students' use of the tools and to reflect on the success of their implementations. The teachers were asked to respond to the online questionnaire from their personal space. Guidelines were given to help teachers to complete the questionnaire items appropriately. The participants were also informed about the objectives of the study and they were assured that individual teacher identities would not be used or presented in the analysis.

\section{Research results}

\section{Teachers' usage of ICT and Web 2.0}

The great majority of the teachers in the sample (87\%) reported that they already had, before entering the program, the necessary skills for using Web and searching information for their professional and instructional needs. On the other hand, only $16 \%$ of them had a previous experience with online discussion forums, $11 \%$ with blogs, $11 \%$ with wikis, while $21 \%$ reported that they had an account in social networking platforms (Facebook and Twitter).

Table 2 shows the mean values of the teachers' actual use and application of ICT as a teaching and learning tool, before attending the Web 2.0 program. It seems that ICT integration in their instruction was not routine in the schools they were coming from. Most of the teachers were restricted to a narrow-range of supplemental tasks, for preparing and supporting their traditional instruction (didactic paradigm). Reiterating the findings of previous studies (Waite, 2004; Jimoyiannis \& Komis, 2007), they were usually getting information from the Internet to prepare their instruction and educational material for their students. Only a small percentage of the teachers in the sample $(26 \%)$ reported using ICT as a learning tool and assignment of ICT-based activities to their students, on a regular basis. 
Table 2

Teachers' use of ICT in their instruction

\begin{tabular}{|c|c|c|c|}
\hline Item & Scale statement & Mean & $S D$ \\
\hline Q15 & I use ICT to prepare and support my instruction & 3.68 & 0.95 \\
\hline Q16 & $\begin{array}{l}\text { I use ICT to create leaflets, tests, and educational material for my } \\
\text { students }\end{array}$ & 4.11 & 0.94 \\
\hline Q17 & $\begin{array}{l}\text { During my instruction, I use a video-projector to show presentations } \\
\text { and/or educational software }\end{array}$ & 3.45 & 1.02 \\
\hline Q18 & $\begin{array}{l}\text { I use ICT-based activities in my class (or in the computer lab) with my } \\
\text { students }\end{array}$ & 3.29 & 1.12 \\
\hline Q20 & $\begin{array}{l}\text { I assign tasks and activities to my students that require using particular } \\
\text { software and the Internet }\end{array}$ & 2.58 & 1.12 \\
\hline
\end{tabular}

\section{Teachers' beliefs and perceptions towards Web 2.0 in instruction}

The second research axis aimed to reveal teachers' beliefs and perceptions of Web 2.0 in relation to its impact on learning and instruction. Table 3 shows the mean values of the teachers' responses across the items of this research dimension. The underlined values represent the items in this questionnaire axis which worded negatively. The original values are in parenthesis. This means that, in the analysis presented in Table 3, those values were reversed to be consistent with the negative (1) - positive (5) attitude scale towards this dimension. In general, the teachers in the sample were positive towards Web 2.0 in education. However, they seem to be undecided regarding the factors determining the traditional view of education, namely the role of the teacher and the textbooks in students' learning.

Table 3

Teachers' instructional beliefs and Web 2.0

\begin{tabular}{|c|c|c|c|}
\hline Item & Scale statement & Mean & $S D$ \\
\hline Q21 & $\begin{array}{l}\text { I believe that my instruction is more effective without using ICT in my } \\
\text { class }\end{array}$ & 1.58 & 0.99 \\
\hline Q22 & I think that the role of the teacher, as knowledge transfer, is irreplaceable & 3.18 & 1.64 \\
\hline Q23 & $\begin{array}{l}\text { I think the role of the textbook in education and students' learning is } \\
\text { indispensable }\end{array}$ & 3.34 & 1.51 \\
\hline Q24 & $\begin{array}{l}\text { I believe that my instruction is more effective without using Web } 2.0 \text { tools } \\
\text { in my class }\end{array}$ & 1.55 & 0.68 \\
\hline Q25 & I think that using Web 2.0 tools in teaching restricts the role of the teacher & 1.58 & 0.96 \\
\hline
\end{tabular}

\section{Teachers' difficulties to use Web 2.0 in their instruction}

This research axis aimed at studying teachers' views and perceptions of the difficulties or barriers to use Web 2.0 in their instruction with their students. Table 4 shows the mean values of the teachers' responses across the items of this research dimension. The majority of the participants stated positively regarding this axis and expressed their readiness toward using Web 2.0 tools in classroom practice.

Table 4

Teachers' difficulties to use Web 2.0 in classroom practice

\begin{tabular}{lllc}
\hline Item & Scale statement & Mean & $S D$ \\
\hline Q26 & $\begin{array}{l}\text { I hesitate to use Web 2.0 tools in my class because I think I need more } \\
\text { specific knowledge and skills }\end{array}$ & 2.11 & 1.33 \\
Q27 & $\begin{array}{l}\text { I hesitate to use Web 2.0 tools in my class because I feel insecure } \\
\text { regarding the educational applications of Web 2.0 }\end{array}$ & 1.68 & 1.10 \\
Q28 & $\begin{array}{l}\text { I hesitate to use Web 2.0 tools in my class because it needs particular } \\
\text { preparation and efforts } \\
\text { I hesitate to use Web 2.0 tools in my class because students are more } \\
\text { experienced with these tools than me }\end{array}$ & 2.18 & 1.23 \\
\hline
\end{tabular}




\section{Teachers' beliefs of the educational potential of Web 2.0}

The fourth research axis consisted of twelve items regarding students' perceptions of the educational potential and the expected value of Web 2.0 in educational practice. As one can see in Table 5, the great majority of the teachers were particularly positive to the items of this dimension, e.g. the participatory, collaborative and learning affordances of Web 2.0 tools. Mean values of responses were ranging from 4.03 up to 4.68 . The underlined mean values were reversed to be consistent with the negative (1) positive (5) attitude scale representing this dimension.

Table 5

Teachers' beliefs of the educational potential of Web 2.0

\begin{tabular}{clcc}
\hline Item & Scale statement & Mean & $S D$ \\
\hline Q30 & $\begin{array}{l}\text { I need more reasons to be convinced about the learning value and the } \\
\text { effectiveness of Web 2.0 tools in practice }\end{array}$ & 1.47 & 0.88 \\
Q31 & $\begin{array}{l}\text { I believe that Web 2.0 applications are just impressive and they cannot } \\
\text { contribute substantially to learning }\end{array}$ & 1.42 & 0.75 \\
Q32 & $\begin{array}{l}\text { I think that using Web 2.0 tools in my class will have a negative impact } \\
\text { on students' development }\end{array}$ & 1.37 & 0.74 \\
Q33 & $\begin{array}{l}\text { I believe that the integration Web 2.0 tools in educational practice } \\
\text { enhances the role of the teacher }\end{array}$ & 4.11 & 1.17 \\
Q34 & $\begin{array}{l}\text { I believe that, using Web 2.0 tools, my instruction would be more } \\
\text { interesting for the students }\end{array}$ & 4.53 & 0.55 \\
Q35 & $\begin{array}{l}\text { I believe that, using Web 2.0 tools in my class, the students would } \\
\text { acquire more knowledge }\end{array}$ & 4.03 & 0.99 \\
Q36 & $\begin{array}{l}\text { I believe that properly designed learning activities with Web 2.0 tools can } \\
\text { enhance students' creativity }\end{array}$ & 4.63 & 0.62 \\
Q37 & $\begin{array}{l}\text { I believe that properly designed learning activities with Web 2.0 tools can } \\
\text { promote student's critical thinking }\end{array}$ & 4.39 & 0.90 \\
Q38 & $\begin{array}{l}\text { I believe that properly designed learning activities with Web 2.0 tools can } \\
\text { promote students' active participation }\end{array}$ & 4.68 & 0.61 \\
Q39 & $\begin{array}{l}\text { I believe that properly designed learning activities with Web 2.0 tools can } \\
\text { support collaborative learning }\end{array}$ & 4.66 & 0.62 \\
\hline $\begin{array}{l}\text { I believe that properly designed learning activities with Web 2.0 tools can } \\
\text { enhance learning by connecting students' homework and class work }\end{array}$ & $\begin{array}{l}\text { I believe that properly designed learning activities with Web 2.0 tools can } \\
\text { enhance learning by extending learning space and time beyond the } \\
\text { boundaries of school }\end{array}$ & 4.37 & 0.54 \\
\hline
\end{tabular} \begin{tabular}{l}
0.96 \\
\hline
\end{tabular}

\section{Teachers' perceptions of Web 2.0 and the educational context}

The fourth research axis concerned the investigation of teachers' perceptions of the contextual issues that determine the integration of Web 2.0 in school practice. There were five items in the questionnaire representing this axis (Table 6). The teachers recognized the need for educational changes and reforms in the curriculum and the pedagogical strategies followed in everyday practice. Moreover, they considered that they need further pedagogical knowledge and reparation to effectively integrate Web 2.0 into their instruction to support students' learning. In addition, question Q42 reiterates the previous neutral results (question Q23) about the role of the textbooks. This indicates that textbooks remain the basic learning resource and are still of considerable value for the teachers in the sample. 
Table 6.

Teachers' beliefs towards the integration of Web 2.0 in education

\begin{tabular}{lllc}
\hline Item & Scale statement & Mean & $S D$ \\
\hline Q42 & $\begin{array}{l}\text { I believe that the preferential role of textbooks in education will be } \\
\text { replaced by new media and Web 2.0 environments } \\
\text { Q believe that I have sufficient knowledge about pedagogical use of } \\
\text { learning activities in practice with Web 2.0 tools }\end{array}$ & 2.97 & 1.14 \\
Q44 & $\begin{array}{l}\text { I believe that I am well prepared to manage the educational changes that } \\
\text { Web 2.0 tools brings in teaching }\end{array}$ & 3.29 & 1.45 \\
Q45 & $\begin{array}{l}\text { The integration of Web 2.0 in classroom requires adjustments to teaching } \\
\text { and learning strategies, that teachers are not yet ready for } \\
\text { The integration of Web 2.0 in the classroom requires substantial changes } \\
\text { in the curriculum }\end{array}$ & 4.08 & 1.04 \\
Q46 & 3.92 & 1.31 \\
\hline
\end{tabular}

\section{Open questions analysis}

From the point of view of the designers and the facilitators of this program, several issues have been revealed through the open questions in the questionnaire. Indicative transcripts, based on teachers' extended reports regarding the research dimensions, are gathered. Critical parameters determining Web 2.0 integration in the schools are also reported.

Q47: Report Web 2.0 tools that you believe they have the potential to improve students' learning.

Blogs and wikis were the most popular tools and were the first choice between the teachers. The great majority of the teachers considered that blogs and wikis could be easily integrated in the classroom, while they are expected to enhance students' learning outcomes. A significant number of teachers reported also Webquests, GoogleDocs and forums, while media sharing and social bookmarking received the interest of a couple of them.

Q48: Describe briefly a couple of indicative examples of Web 2.0-based learning tasks that you think you are able to implement with your students

The great majority of the teachers have developed productive reflections on their experience with this particular program. The following statements are representative of many similar responses to this question. They show increased confidence regarding the integration of Web 2.0 tools in the classroom:

Up to now I used Power-Point presentations and Facebook to provide educational material and assignments to my students. I am now confident to use blogs and wikis as well.

I have already set a Chemistry blog and my students (K-9) are engaged in blogging activities. The themes under study include acids, bases, salts and other subjects presented into the Program of Studies."

I would be able to use a project-like long term activity based on wikis, blogs or a Webquest.

I plan to implement a collaborative authoring activity, e.g. a wiki lexicon related to subjects in my courses.

On the other hand, two teachers wrote:

No because of infrastructure problems in my school. There is only one Internet connection point in the computer lab. I have no Internet access in my classroom

I am not able to integrate Web 2.0 in my particular class (students with special needs).

Q49: In the coming year, do you have plans to integrate Web 2.0 learning activities into your course? Give reasons for your choice?

The majority of the teachers were particularly positive to incorporate Web 2.0 in their instruction. The following quotes are indicative and show that the majority of the teachers have built a complete view of the Web 2.0 and its integration in classroom practice: 
Absolutely yes!... I want my students to receive meaningful learning experiences and realise that computers can be an important tool for working and learning and not just a stupid game tool...

Of course, yes!. In my first attempt with blogging I noticed that my students were all engaged, even those with low or no interest about my subject.

Yes, I believe that learning is not restricted into the classroom limits. Web 2.0 can support communication and collaboration every day and any time.

Yes, I plan to use a wiki because it can be built though both school and home-work. Wikis promote collaboration and group work, support critical thinking and constitute a creative and enjoyable task. I am thinking of a wiki about Ancient Greek mathematicians, and their contribution to the mathematical knowledge ...

I think that the Greek schools should take advantage of the new Web 2.0 technologies to engage students in collaborative and productive learning activities, in order to transform instruction to a purposeful and effective task.

On the other hand, one teacher wrote:

Not yet. I do not feel very confident to try this.

Q50: What are the main difficulties (barriers) for you personally to integrate Web 2.0 in your instruction?

We summarise the main barriers to integrate Web 2.0 in their instruction reported by the teachers in their written responses:

- $\quad$ Difficulties to plan their instructional choices and to design learning activities based on Web 2.0

- $\quad$ Lack of time to design learning activities based on Web 2.0

- Lack of resources available in the schools-classrooms

- Restrictions and the need to cover the content set by the national curriculum

- $\quad$ Lack of time for further training and developing Web 2.0 technical skills

- The parents. An indicative quote is the following:

There are many parents with no computer skills or lacking the skills to use ICT; they are also cautious or unsafe when their children use Internet applications...

Q51: To what degree do you consider your expectations of this particular training program were covered?

The great majority of the teachers were satisfied from the program they attended and reported that it had a positive impact into their professional development. The following statements are representative of many similar responses to this question:

The course sessions were structured perfectly. We acquired new knowledge and the process of introducing us to the new tools was very effective.

'It was my first experience with the Web 2.0 tools. The course was the first step towards a meaningful understanding and using Web 2.0 tools in the classroom.

At a high level, because the course sessions combined theory and practice in an appropriate way...

At a very satisfactory level, though I think that we need more training hours for this broad subject

I am satisfied more than I expected...

On the other hand, one teacher expressed a different view:

... At a moderate degree, because I cannot use Web 2.0 tools in my classroom. The philosophy of using Web 2.0 in education was based on contemporary pedagogy which I know from my University studies... but this is an impersonal and non experienced way of teaching ... 
Q52: What do you want to be included in a future training program about Web 2.0?

According to their responses, the teachers in the sample seem to need more educational examples of Web 2.0-based learning activities applicable in practice, more practice on technical and instructional design themes, and opportunities to collaborate with colleagues. The following transcripts are representative of their training needs:

I need more complete examples regarding the educational practice with Web 2.0 tools...

I think we need more time to design learning tasks and integrate Web 2.0 to the existing curriculum.

I would preferred to complete a whole project in collaboration with the other participants

I want to know e-portfolios and any new Web 2.0 tool, because of their rapid development.

Further investigation of the issues above and analysis of teachers' responses are currently in progress, in addition to the qualitative data recorded during the follow-up face-to-face meeting, which took place six months after the end of the courses, at the Department of Social and Educational Policy, University of Peloponnese.

\section{Discussion}

In examining how learning models and pedagogy are changing, this paper reported on the development of a Web 2.0 pedagogical framework and its implementation in a teachers' training program. The model drawn treats Web 2.0 not as a simple technology but in an integrated pedagogical framework rooted on the TPACK model (Mishra \& Koehler, 2006) and the authentic learning approach (Herrington \& Kervin, 2007).

The exploratory study showed that the proposed Web 2.0 framework helped teachers to acquire the knowledge and skills to integrate Web 2.0 tools in their instruction. The teachers who participated in the pilot training courses considered Web 2.0 as an efficient learning environment that could be applied in their classroom practice. The great majority of the teachers were satisfied with the program and perceived that it had a positive impact into their development towards Web 2.0. In addition, our findings showed that teachers exhibited positive perceptions of the educational benefits of Web 2.0 and the expected outcomes for the students. They also revealed teachers' willingness to adopt and use Web 2.0 in their classroom, in order to improve their instruction and enhance students' learning. On the other hand, the teachers in the sample considered that lack of time, classroom infrastructure, and the restrictions set by the national curriculum as the main factors determining their intentions and efforts to put Web 2.0 into practice.

Since this study was based on a convenience sample, generalizations to other educational environments should be done with specific care. However, the research results could be of interest and significance in broader or international educational contexts. In summary, the outcomes suggested that the proposed Web 2.0 framework in conjunction with teachers' active engagement to design Web 2.0-based learning activities, applicable in their classrooms, was particular effective in helping participants to understand (a) the educational potential of Web 2.0 tools; and (b) how they can purposefully integrate Web 2.0 in their regular instruction.

If Web 2.0 learning activities are to be deployed effectively across classroom settings, teachers, students and the schools need to develop shared strategies and mutual understandings around the participatory, open, collaborative, networking, co-creating and collective aspects of Web 2.0. The proposed Web 2.0 instructional design framework could offer learning activities harnessing the organizational and pedagogical features of Web 2.0 environments and also the potential to support reflective learning and deeper understanding, through sharing resources, expressing and exchanging ideas, interaction and collaboration, critical and reflective thinking, group work and social networking.

Undoubtedly, there are still many issues open to clarify, once the nature of Web 2.0 has been understood by the teachers. For example, what educational practices are feasible in school practice around Web 2.0 
technologies?; how could we promote and enhance students' participation and the consequent learning outcomes in Web 2.0 learning spaces?; what are the main Web 2.0 implementation problems in school practice?; how could we assess and evaluate students' learning through Web 2.0? These could be some indicative questions for future research directed to respond to the new needs for researching ICT pedagogy and Web 2.0 (Webb, 2013).

\section{Implications for practice}

This study has the ambition to be of value for both teachers and developers to deliver efficient Web 2.0 learning environments. The findings demonstrated that careful attention to the theoretical foundation of the instructional design framework, a balance between theoretical and practical issues, and the teachers' engagement and collaborative work, were the critical parameters that made this program successful. The theoretical framework presented and the empirical research phase of the paper addressed some of the critical issues arising around Web 2.0 in school practice. TPACK 2.0 and authentic learning can develop and support a coherent pedagogical and instructional framework for future teacher professional development programs aiming to help educators:

- to adopt Web 2.0 not as a matter of acquiring new ICT skills but in terms of specific pedagogical and instructional dimensions;

- to move beyond oversimplified approaches which treat Web 2.0 as a 'trend', a 'special event' or an 'extra tool' supplemental to their traditional instruction;

- to understand how Web 2.0 technologies change both pedagogy and learning practice;

- to consider, in their instructional design, Web 2.0 technologies, Content and Pedagogy not in isolation, but in the complex relationships system they define.

In this particular respect, educational policy should clearly address the objectives of the contemporary curriculum to a wider view and a more flexible response to the affordances offered by Web 2.0 rather than to apply an add-on, proscriptive use of Web 2.0 in conventional classroom settings.

\section{Conclusion}

In this paper we have presented a Web 2.0 educational framework aiming to support both teachers' professional development and the integration of Web 2.0 tools in regular classroom practices. The model of technological pedagogical content knowledge and the authentic learning approach were the guiding principles that influenced the proposed Web 2.0 pedagogical framework which was applied in a teacher preparation program. The paper ends with two main conclusions: (a) teachers' readiness and competence regarding the educational applications of Web 2.0 goes well beyond the ability to use social media and Web 2.0 applications for personal purposes; (b) providing a holistic and coherent framework around the educational Web 2.0 can help teachers to adopt Web 2.0 as an important and efficient learning space to be integrated in their instructional practices.

\section{Acknowledgments}

This work has been supported by the Lifelong Learning Programme, European Commission Education, Audiovisual and Culture Executive Agency (EACEA). Grant Agreement Number: N.504839-LLP-12009-1-UK-KA3-KA3MP.

\section{References}

Anderson P. (2007). What is Web 2.0? Ideas, technologies and implications for education. JISC Technology and Standards Watch, Joint Information Systems Committee, UK. Retrieved from http://www.jisc.ac.uk/media/documents/techwatch/tsw0701b.pdf

Angelaina, S., \& Jimoyiannis, A. (2011). Educational blogging: Developing and investigating a students' community of inquiry. In A. Jimoyiannis (Ed.), Research on e-Learning and ICT in education (pp. 167-180). New York: Springer. 
Bennett, S., Maton, K., \& Kervin, L. (2008). The 'digital natives' debate: A critical review of the evidence. British Journal of Educational Technology, 39(5), 775-786.

Bolliger, D. U., \& Shepherd, C. E. (2010). Student perceptions of ePortfolio integration in online courses. Distance Education, 31(3), 295-314.

Ching, Y.-H. \& Hsu, Y.-C. (2011). Design-grounded assessment: A framework and a case study of Web 2.0 practices in higher education. Assessing students' Web 2.0 activities in higher education. Australasian Journal of Educational Technology, 27(5), 781-797.

Clark W., Logan K., Luckin R., Mee A. \& Oliver M. (2009). Beyond Web 2.0: mapping the technology landscapes of young learners. Journal of Computer Assisted Learning, 25(1), 56-69.

Dahlstrom, E., de Boor, T., Grunwald, P., \& Vockley, M. (2011). The ECAR National Study of Undergraduate Students and Information Technology 2011 (Research Report). Boulder. CO: EDUCAUSE Center for Applied Research. Retrieved from http://www.educause.edu/ecar

Davis, N., Preston, C., \& Sahin, I. (2009). Training teachers to use new technologies impacts multiple ecologies: Evidence from a national initiative. British Journal of Educational Technology, 40(5), 861878.

Dede, C. (2008). A seismic shift in epistemology. EDUCAUSE Review, 43(3), 80-81. Retrieved from http://net.educause.edu/ir/library/pdf/ERM0837.pdf

Deng, L. \& Yuen, H. K. (2011). Understanding student perceptions and motivation towards academic blogs: An exploratory study. Australasian Journal of Educational Technology, 28(1), 48-66.

Doering, A., Veletsianos, G., Scharber, C., \& Miller, C. (2009). Using the Technological, Pedagogical, and Content Knowledge Framework to design online learning environments and professional development. Journal of Educational Computing Research. 41(3), 319-346.

Doherty, I. (2011). Evaluating the impact of educational technology professional development upon adoption of Web 2.0 tools in teaching. Australasian Journal of Educational Technology, 27(3), 381396.

Glassman, M., \& Kang, M. J. (2010). Pragmatism, connectionism and the Internet: A mind's perfect storm. Computers in Human Behavior, 26, 1412-1418.

Hall, R., \& Hall, M. (2010). Scoping the pedagogic relationship between self-efficacy and Web 2.0 technologies. Learning, Media and Technology, 35(3), 255-273.

Hennessy, S., Wishart, J., Whitelock, D., Deaney, R., Brawn, R., la Velle, L., McFarlane, A., Ruthven, K., \& Winterbottom M. (2007). Pedagogical approaches for technology-integrated science teaching. Computers \& Education, 48(1), 137-152.

Herrington, J., \& Kervin, L. (2007). Authentic learning supported by technology: Ten suggestions and cases of integration in classrooms. Educational Media International, 44(3), 219-236.

Holden, H., Ozok, A., \& Rada, R. (2008). Technology use and acceptance in the classroom: Results from an exploratory survey study among secondary education teachers in the USA. Interactive Technology and Smart Education, 5(2), 113-134.

Jimoyiannis, A. (2008). Factors determining teachers' beliefs and perceptions of ICT in education. In A. Cartelli \& M. Palma (Eds.), Encyclopedia of Information Communication Technology (pp. 321-334), Hershey, PA: IGI Global. 
Jimoyiannis, A. (2010a). Designing and implementing an integrated Technological Pedagogical Science Knowledge framework for science teacher's professional development. Computers \& Education, 55(3), 1259-1269.

Jimoyiannis, A. (2010b, April). Integrating Web 2.0 in education: Towards a framework for Pedagogy 2.0. In R. Hackney \& C. Evans (Eds.), Web 2.0 Conference Abstracts (p. 5). Brunel University, London.

Jimoyiannis, A., \& Komis, V. (2007). Examining teachers' beliefs about ICT in education: implications of a teacher preparation programme, Teacher Development, 11(2), 149-173.

Kennedy, G., Judd, T., Dalgarno, B. \& Waycott J. (2010). Beyond natives and immigrants: exploring types of net generation students. Journal of Computer Assisted Learning, 26(5), 332-343.

Koehler, M. J., \& Mishra, P. (2009). What is technological pedagogical content knowledge?. Contemporary Issues in Technology and Teacher Education, 9(1), 60-70.

Levin, T., \& Wadmany, R. (2008). Teachers' views on factors affecting effective integration of information technology in the classroom: Developmental scenery. Journal of Technology and Teacher Education, 16(2), 233-263.

Lee, M.-H., \& Tsai, C.-C. (2009). Exploring teachers' perceived self efficacy and technological pedagogical content knowledge with respect to educational use of the World Wide Web, Instructional Science, 38, 1-21.

Marsden, N., \& Piggot-Irvine, E. (2012). Using blogging and laptop computers to improve writing skills on a vocational training course. Australasian Journal of Educational Technology, 28(1), 30-47.

McLoughlin, C., \& Lee, M. J. W. (2010). Personalised and self-regulated learning in the Web 2.0 era: International exemplars of innovative pedagogy using social software. Australasian Journal of Educational Technology, 26(1), 28-43.

Mishra, P., \& Koehler, M. J. (2006). Technological Pedagogical Content Knowledge: A framework for teacher knowledge. Teachers College Record, 108(6), 1017-1054.

OFSTED (2004). ICT in schools 2004: The impact of government initiatives five years on. London: Office for Standards in Education. Retrieved from http://www.ofsted.gov.uk/resources/ict-schools2004-impact-of-government-initiatives-five-years

OFSTED (2011). ICT in schools: An evaluation of information and communication technology education in schools in England 2008-11. London: Office for Standards in Education. Retrieved from http://www.ofsted.gov.uk/resources/ict-schools-2008-11.

O'Reilly, T. (2005). What is Web 2.0: Design patterns and business models for the next generation of software. Retrieved from http://oreilly.com/pub/a/web2/archive/what-is-web-20.html?page=1

Pea, R. D. (2004). The social and technological dimensions of scaffolding and related theoretical concepts for learning, education, and human activity. Journal of the Learning Sciences, 13(3), 423-451.

Pence, H. E. (2007). Preparing for the real web generation. Journal of Educational Technology Systems, 35(3), 347-356.

Prensky, M. (2001). Digital natives, digital immigrants. On the Horizon, 9(5), 1-6.

Putnam, R. T., \& Borko, H. (2000). What do new views of knowledge and thinking have to say about research on teacher learning?. Educational Researcher, 29(1), 4-15. 
Ravenscroft, A. (2009). Social software, Web 2.0 and learning: status and implications of an evolving paradigm. Journal of Computer Assisted Learning, 25, 1-5.

Roussinos, D., \& Jimoyiannis, A. (2011). Blended collaborative learning through a wiki-based project: A case study on students' perceptions. International Journal of Digital Literacy and Digital Competence, $2(3), 15-30$.

Sheehy, G. (2008). The wiki as knowledge repository: using a wiki in a community of practice to strengthen K-12 education. TechTrends, 52(6), 55-60.

Shulman, L. S. (1986). Those who understand: knowledge growth in teaching. Educational Researcher, 15(2), 4-14.

Siemens, G. (2005). Connectivism: A learning theory for the digital age. Retrieved from http://www.elearnspace.org/Articles/connectivism.htm

So H.-J., \& Kim, B. (2009). Learning about problem based learning: Student teachers integrating technology, pedagogy and content knowledge. Australasian Journal of Educational Technology. 25(1), 101-116.

Stahl, G. (2005). Group cognition in computer-assisted collaborative learning. Journal of Computer Assisted Learning, 21, 79-90.

Tondeur, J., van Keer, H., van Braak, J., \& Valcke M. (2008). ICT integration in the classroom: Challenging the potential of a school policy. Computers \& Education, 51(1), 212-223.

Tse, S. K., Yuen, A. H. K., Loh, E. K. Y., Lam, J. W. I., \& Ng, R. H. W. (2010). The impact of blogging on Hong Kong primary school students' bilingual reading literacy. Australasian Journal of Educational Technology, 26(2), 164-179.

Underwood, J. D. M. (2007). Rethinking the digital divide: impacts on student-tutor relationships. European Journal of Education, 42(2), 213-222.

Vygotsky, L.S. (1978). Mind in Society. Cambridge, MA: Harvard University Press.

Waite, S. (2004). Tools for the job: a report of two surveys of information and communications technology training and use for literacy in primary schools in the West of England. Journal of Computer Assisted Learning, 20(1), 11-20.

Webb, M. (2013). Changing models for researching pedagogy with information and communications technologies. Journal of Computer Assisted Learning, 29(1), 53-67.

Wheeler, S., \& Wheeler, D. (2009). Using wikis to promote quality learning in teacher training. Learning, Media and Technology, 34(1), 1-10.

Wikan, G., \& Molster, T. (2011). Norwegian secondary school teachers and ICT. European Journal of Teacher Education, 34(2), 209-218.

Wojtowicz, A., Walczak, K., Wiza, W., \& Ruminski, D. (2011). Web platform with role-based security for decentralized creation of Web 2.0 learning content. In A. Abraham, E. Corchado, S.-Y. Han, W. Guo, J. Corchado, \& A. Vasilakos (Eds.), Proceedings of the 7th International Conference on Next Generation Web Services Practices (pp. 523-529), Salamanca, Spain, IEEE.

Woo, M., Chu, S., Ho, A., \& Li, X. (2011). Using a wiki to scaffold primary-school students' collaborative writing. Educational Technology \& Society, 14(1), 43-54.

Wopereis, I. G. J. H., Sloep, P. B., \& Poortman, S. H. (2010). Weblogs as instruments for reflection on action in teacher education. Interactive Learning Environments, 18(3), 245-261. 
Yang, S.-H. (2009). Using blogs to enhance critical reflection and Community of Practice. Educational Technology \& Society, 12(2), 11-21.

Zickuhr, K. (2010). Generations 2010. Washington DC, Pew Internet and American Life project. Washington: Pew Research Center. Retrieved from http://pewinternet.org/ /media//Files/Reports/2010/PIP_Generations_and_Tech10.pdf

Zorko, V. (2009). Factors affecting the way students collaborate in a wiki for English language learning. Australasian Journal of Educational Technology, 25(5), 645-665.

Corresponding author: Athanassios Jimoyiannis, ajimoyia@uop.gr

Australasian Journal of Educational Technology (C) 2013.

Please cite as: Jimoyiannis, A., Tsiotakis, P., Roussinos, D., \& Siorenta, A. (2013) Preparing teachers to integrate Web 2.0 in school practice: Toward a framework for Pedagogy 2.0. Australasian Journal of Educational Technology, 29(2), 248-267. 